\title{
亜脱臼性股関節症に対する寛骨臼移動術の成績
}

九州大学医学部整形外科
野 口
神宮司 誠 也・馬 渡 正 明
福 岡 真 二・佛 淵 孝 夫

\section{Transposition osteotomy of the acetabulum for osteoarthritis secondary to hip dysplasia}

by

\author{
Yasuo Noguchi, Takao Hotokebuchi, Seiya Jingushi, Masaaki Motai, \\ Shinji Fukuoka and Yoichi Sugioka \\ Department of Orthopaedic Surgery, Faculty of Medicine, Kyushu University
}

\begin{abstract}
Transposition osteotomy of the acetabulum has been performed since 1956 and is a circumacetabular osteotomy for the dysplastic hip. Of 178 procedures, carried out for osteoarthritis in dysplastic hips, some of which were performed by Nishio himself, we were able to review 102 hips after 2 to 17 years (mean 5.7 years). The clinical result, evaluated according to the Japanese Orthopaedic Association hip score, was exellent (over 90) in 42\%, good (80-89) in 26\%, fair (65-79) in $23 \%$ and poor (less than 65 ) in $9 \%$. The results depended on the stage of the disease, that is, the more advanced the stage, the poorer the result. No cases have undergone secondary total hip arthroplasty to date. Adequate medialization, as well as good lateral and anterior coverage, was significantly related to achieving good results. An early stage of osteoarthritis in severely dysplastic hips is thought to be the best indication for this procedure.
\end{abstract}

Key words : Acetabular dysplasia (臼蓋形成不全), Osteoarthritis of the hip (変形性股関節症), Transpositon osteotomy of the acetabulum（寛骨臼移動術）

はじめに

亜脱臼性股関節症に対して寛骨曰を堀り出して移動 することにより被覆を良くし，関節の安定性を得ると いう寛骨臼移動術を1956 年に西尾は世界にさきがけ て報告している ${ }^{3)}$. 九州大学整形学科では亜脱臼性股 関節症に対する骨切り術として, 弯曲内反骨切り術 （西尾）之寛骨臼移動術を，主に臼蓋形成不全の程度 によって使い分けてきており，寛骨臼移動術の成績も すでに報告してきた ${ }^{122)}$ ．今回我々は，第 89 回西日本 整形災害外科学会の主題として「亜脱臼性股関節症に 対する骨切り術」が取り上げられたのを機会に，九州
大学整形外科において行われた寛骨臼移動術の成績を 再度調查し，検討を行ったので報告する．

\section{症例亡方法}

九州大学整形外科で要脱臼性股関節症に対して 1992 年までに寛骨臼移動術を施行した症例は 178 関 節であり, そのうち実際に 2 年以上経過観察でき, カ ルテおよびX線がそろっている 102 関節を検討の対象 とした．X線病期別では前関節症 34 関節，初期関節 症 44 関節，進行期関節症 17 関節，末期関節症 7 関節 で，追跡期間は 2 年から 17 年，平均 5 年 8 か月であ

る. 合併手術として外反骨切りを行った関節は 7 関節 
あり，その内訳は初期 2 関節，進行期 4 関節，末期 1 関節である.

これらの症例に対し, 経年的に臨床症状, 理学的所 見，X線所見を検討した。臨床成績およびX線像の変 化は日整会股関節症判定基準（臨床評価は「JOA ス コア」，X線評価は「X線スコア」と略す）を用いて 評価した。 X線計測値として, Center-Edge Angle (CE 角), Acetabular-Head Index（AHI），臼蓋荷 重部傾斜角, 骨頭高位指数, 骨頭外方指数 ${ }^{2}$ を術前後 のX線像で計測し，手術による寛骨臼の被覆の改善お よび移動方向を明かにし，またX線計測値の変化と術 後の JOA スコアとの相関を検討し，䙾骨臼の適切な 移動方向などを明かにした.

次に関節適合性と成績との関連を知るために，適合 性が特に問題となる進行期および末期の症例を対象に 検討した，分析を簡便化するために関節適合性の指標 としては骨頭形態 (変形) を用い, 円形, 卵形, 三角 形および多角形の 4 型に分類し, 術前および術後 2 年 の JOA スコアとの相関を検討した.

さらに追加手術例や成績不良例の原因の検討を行い, 合併症についても調查した. 外反骨切り術併用例は症 例数も少なく今回は特別な検討は行わなかった.

\section{結果}

\section{JOA スコアの推移}

X線病期別の JOA スコアの術前および術後 2 年と 5 年の平均値を表 1 に示す。前関節症および初期関節 症では 5 年後まで良好な成績を示す。進行期関節症は
術後 2 年では良好であるが, 術後 5 年でスコアはやや 悪化を示した．末期股関節症は平均的には 70 点以下 であり成績は不良であったが, 術後 2 年より 5 年の方 がやや改善を示した．末期例でも一部には良好な経過 をとる症例むみられた（図1).

$\mathrm{X}$ 線病期別の全症例の JOA スコアの推移を図 2 に 示す. 前関節症, 初期関節症および進行期関節症のい ずれむ，一部に不良な経過を示した症例はあるが，大 半は臨床成績は良好であることが分かる．一方，末期 例は臨床症状の改善はみられることが多いが，そのス コアは進行期までし比較すると低い。

さらにJOA スコアを 4 つのカテゴリー，即ち優 (90-100), 良 (80-89), 可 (65-79), 不可 (65未満) に分けて検討すると図 3 のようになる。症例は 5 年以 上経過観察できた症例に限定した．前関節症および初 期関節症では大半が術後 5 年を経過してあ 80 点以上 の優または良を示すが，進行期では可，および不可が 増加し，末期ではその大半が可または不可となってい た. 最終時の JOA スコアでは優 43 関節, 良 27 関節, 可 23 関節，不可 9 関節となっていた.

JOA スコアの変化をさらに詳しく検討すると, JOA スコアの改善はは主に疼痛のスコアであり, こ れに歩行能力が次いでいた．可動域は一般に外転が少 し制限されるが，前関節症ではスコアの悪化は殆ど見 られないのに対して, 初期, 進行期と病期が進むにつ れて可動域のスコアの悪化がしばしば見られた。

\section{X線スコアの変化}

$\mathrm{X}$ 線病期別の $\mathrm{X}$ 線スコアの術前および術後 2 年と 5

表 1 JOA スコアおよびX線スコアの推移

\begin{tabular}{llccc}
\hline \hline & & 症例数 & JOA スコア & X線スコア \\
\hline \multirow{3}{*}{ 前関節症 } & 術前 & 34 & $77 \pm 10$ & $80 \pm 6$ \\
& 術後 2 年 & 34 & $91 \pm 11$ & $81 \pm 11$ \\
& 術後 5 年 & 16 & $91 \pm 10$ & $79 \pm 11$ \\
\hline \multirow{3}{*}{ 初期 } & 術前 & 44 & $69 \pm 11$ & $61 \pm 7$ \\
& 術後 2 年 & 44 & $86 \pm 9$ & $69 \pm 13$ \\
& 術後 5 年 & 15 & $86 \pm 10$ & $64 \pm 9$ \\
進行期 & 術前 & 17 & $61 \pm 12$ & $46 \pm 6$ \\
& 術後 2 年 & 17 & $80 \pm 12$ & $54 \pm 17$ \\
& 術後 5 年 & 5 & $71 \pm 9$ & $42 \pm 17$ \\
末期 & 術前 & 7 & $56 \pm 11$ & $25 \pm 5$ \\
& 術後 2 年 & 7 & $64 \pm 14$ & $33 \pm 7$ \\
& 術後 5 年 & 6 & $68 \pm 11$ & $38 \pm 9$ \\
\hline
\end{tabular}

(平均土標準偏差) 


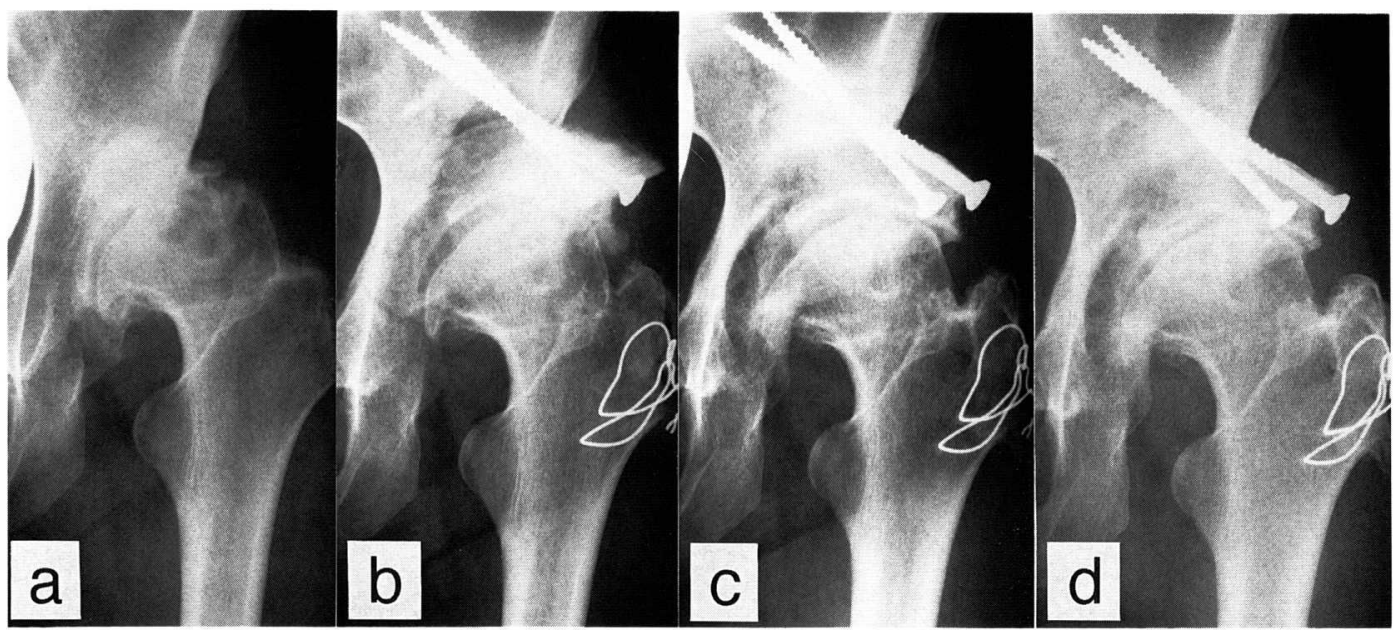

図 134 歳女性，末期股関節症．術前（a)，骨頭変形も強く関節適合性も不良だが，手術により良好な被覆と内方化が得ら れ, 術後 2 か月（b）では外側の関節裂隙が狭く不適合を示すが, 術後 2 年（c）では適合性も改善し, 術後 12 年でも 適合性は良く，関節症の進行をみない.JOA スコアは術前 64 点, 術後 12 年で 89 点.

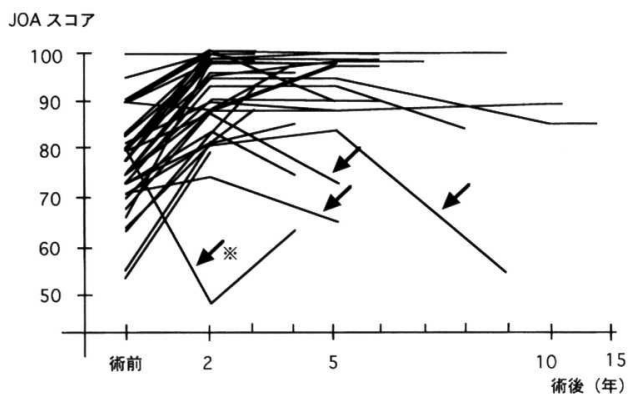

a

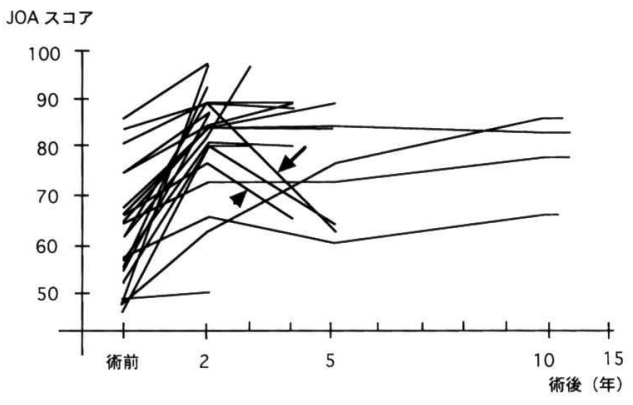

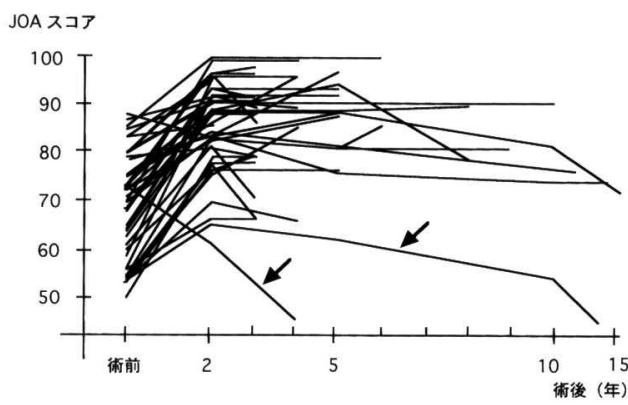

b

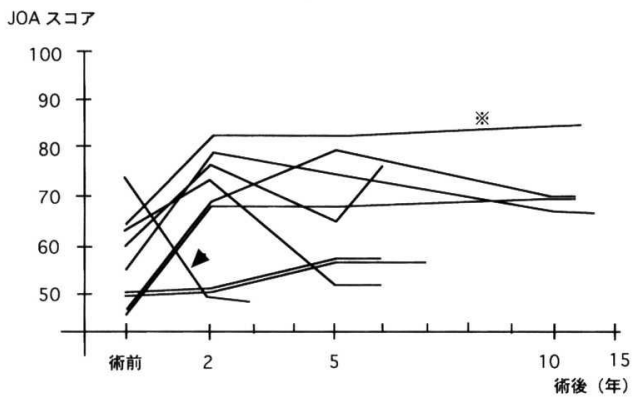

d

図 2 全症例のX線病期別 JOA スコアの推移

a．前関節症．矢印は被覆不良や外方化による成績不良例である．※印は図 5 の症例.

b. 初期関節症. 矢印は被覆不良や外方化による成績不良例.

c. 進行期関節症. 矢印は被覆不良や外方化による成績不良例. 矢じりは被覆, 内方化は良好だが関節適合性が不良によ る成績不良例.

d. 末期関節症. ※印は図 1 の症例. 矢じりは骨頭および臼蓋の骨破壊が急速に進行し骨壊死が疑われた症例. 

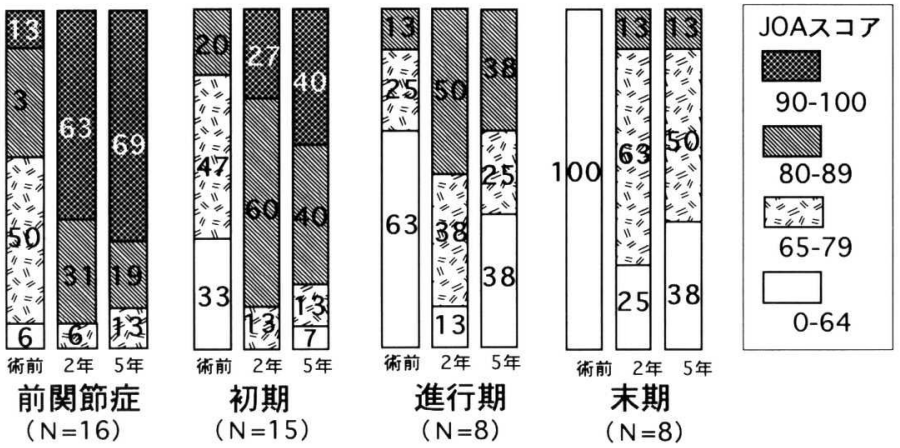

図 3 X 線病期別の JOA スコアの推移. 手術による改善は全病期を通じてみら れるが, 術前の病期が進んでいるほど術後の成績は不良である.

年の平均值を表 1 に示す。前関節症では定義上当然の ことながら術前から変化は少なく, 術後も悪化するこ となく術後 5 年までほぼ同じ值を示している。初期お よび進行期では術前に比べて, 術後 2 年では関節裂隙 の拡大や骨硬化像の軽減, 骨囊胞の消失などでスコア が改善するが，骨棘はむしろ増加することが多い，術 後 5 年を越える関節数は術後 2 年のやく $1 / 3$ と少なく 一概には言えないが，X線スコアは 5 年経過時には悪 化する関節が多く, 関節症変化の進行が見られた。こ れに対して末期例では, 術前すでに最低点の 20 点に 近い極めて低いスコアから術後 2 年, および術後 5 年 と経過年数に従ってスコアの改善が見られてきている.

\section{3. 手術前後のX線計測値の変化と成績}

手術により股関節の形態は表 2 に示すように CE 角 は術前の平均 $-8^{\circ}$ から術後には $27^{\circ}, \mathrm{AHI}$ も $49 \%$ か ら $87 \%$ へ, 臼蓋による骨頭の被覆は良好に改善さ れている. また, 臼蓋荷重部傾斜角もほぼ水平化し, 安定した関節となっている，骨頭中心の位置は術前よ り術後は指数にして上方に 0.05 , 内側に 0.06 移動し, これは平均的な大きさの骨盤では, 上方に $3 \mathrm{~mm}$, 内側 へ $4 \mathrm{~mm}$ の移動に相当する. 関節裂隙は術直後やや開大 している.

術直後のX線計測值と臨床成績との関係を見るため に, 術後 2 年の JOA スコアが 80 点以上の 77 関節と 80 点未満の 25 関節との 2 群に分け, 両群の術後の CE 角, AHI, E蓋荷重部傾斜角, 骨頭高位指数, 骨 頭外方指数を $\mathrm{t}$ 検定で比較した結果, 骨頭外方指数の み危険率 $1 \%$ 以下で統計学的有意差が見られ, 術後 2 年の JOA スコアが 80 点以上の関節が 80 点未満の関 節より明かに骨頭が術後内側寄りにあることが分かっ
表 2 寛骨臼移動術前後のX線計測值の変化

\begin{tabular}{lcc}
\hline \hline & 術前 & 術直後 \\
\hline CE 角 (Wiberg) & $-8 \pm 10$ & $27 \pm 13$ \\
田蓋 骨 頭 指 数 & $49 \pm 10$ & $87 \pm 13$ \\
(AHI) & $34 \pm 8$ & $3 \pm 12$ \\
臼蓋荷重部傾斜角 & $0.35 \pm 0.09$ & $0.40 \pm 0.11$ \\
骨頭高位指数 & $0.75 \pm 0.12$ & $0.69 \pm 0.15$ \\
骨頭外方指数 & $3.0 \pm 1.9$ & $3.3 \pm 1.7$ \\
\hline
\end{tabular}

(平均土標準偏差)

表 3 術後 2 年の JOA スコア上骨頭上方化との関係

\begin{tabular}{|c|c|c|c|}
\hline & & 術後 2 年 0 & スコア \\
\hline & & $80-100$ & $0-79$ \\
\hline & 0.05 以上増加 & 45 & 17 \\
\hline 指数 & $\begin{array}{l}0.04 \text { 以下の増加 } \\
\text { または減少 }\end{array}$ & 32 & 15 \\
\hline
\end{tabular}

表 4 術後 2 年の JOA スコアと骨頭内方化との関係

\begin{tabular}{|c|c|c|c|}
\hline & \multicolumn{2}{|c|}{ 術後 2 年の JOA スコア } \\
\hline & & $80-100$ & 0-79 \\
\hline \multirow{2}{*}{$\begin{array}{l}\text { 骨頭外方 } \\
\text { 指数 }\end{array}$} & 0.05 以上増加 & 52 & 11 \\
\hline & $\begin{array}{l}0.04 \text { 以下の増加 } \\
\text { または減少 }\end{array}$ & 24 & 13 \\
\hline
\end{tabular}

た.さらに，手術による骨頭の位置の変化と成績を検 討するために, 術後 2 年の JOA スコアと骨頭高位指 数および骨頭外方指数との関連を見た結果が表 3 およ び表 4 である．寛骨田移動術では骨頭は上方へ指数之 して平均的に 0.05 移動する。 そこで上方化の成績へ の影響を見るために明らかな上方化（指数として 0.05 
以上）がある関節とない関節に分けて検討したが，そ の結果は上方化は成績とはあまり関連は見られなかっ た。 下方へ移動する関節は数が少ないため，下方への 移動と成績との関連は検討できなかった。一方，骨頭 の明らかな内方への移動（指数として 0.05 以上）が ある関節は, 内方移動のない関節に比べて術後 2 年の JOA スコア 80 点以上の割合が有意に高いという結果 であった。

\section{4，適合性と JOA スコアとの関連}

関節適合性と成績との関連を知るために，特に問題 となる進行期および末期の症例について, 関節適合性 の一つの指標として骨頭変形により 2 群に分けて JOA スコアを比較した。 その結果, 適合性が良いと 思われる円形および卵形の関節では術前が平均 62.2 点, 術後 2 年で平均 85.3 点であったのに対し, 適合 性に問題のある三角形および多角形の関節では術前の 時点では平均 59.4 点之有意差がないが, 術後 2 年の スコアは 69.1 点と明かに劣っており（ $\mathrm{t}$ 検定; 危険 率 $0.1 \%$ 以下), 関節適合性と成績の関連が明かとなっ た.

\section{5。追加手術}

経過観察出来た症例の中で, その後に追加手術を行っ た症例は 1 関節のみであった。この症例は前関節症の 症例で，術前のX線では $\mathrm{CE}$ 角 $-24^{\circ}, \mathrm{AHI} 27 \%$ ， 白 蓋荷重部傾斜角 $49^{\circ}$ という極めて臼蓋形成不全が高度
な例で，なおかつ強い前捻および外反股を呈していた 手術による被覆が不十分で, 疼痛の改善む不十分であっ たため, 西尾式弯曲内反骨切り術を追加し, 症状は軽 快した（図4).

人工関節置換術を行った症例は現在までのところ皆 無である.

\section{6. 不良例の検討}

術前より最終時の JOA スコアが悪化した関節は前 関節症 4 関節，初期関節症 3 関節，進行期関節症 2 関 節，末期関節症 2 関節である。悪化した関節のX線像 を検討すると，前および初期関節症では寛骨臼の不適 切な移動，特に被覆不十分（前方书よび側方）と外方 移動が見られ，進行期および末期ではそれに加えて骨 頭変形などによる関節適合性の不良が見られた。図 5 は不十分な前被覆のために関節の不安定性が残存した のが関節症の進行に関与したと考えられた症例である.

\section{7. 合併症}

荷重部関節面への切り込みが 2 関節あり, 初期の 1 関節はリモデリングにより臨床成績は現在のところ良 好に経過しているが（図 6 ），末期の 1 関節は成績が 不良となった。移動骨片の明らかな壊死を示した関節 はないが，術後急速に寛骨臼打よび骨頭の破壊を生じ た末期股関節症例があり，その原因として骨壊死の可 能性も考えられた，軽度の異所性骨化はときどき見ら れるが，関節拘縮を来たす高度の異所性骨化が初期関

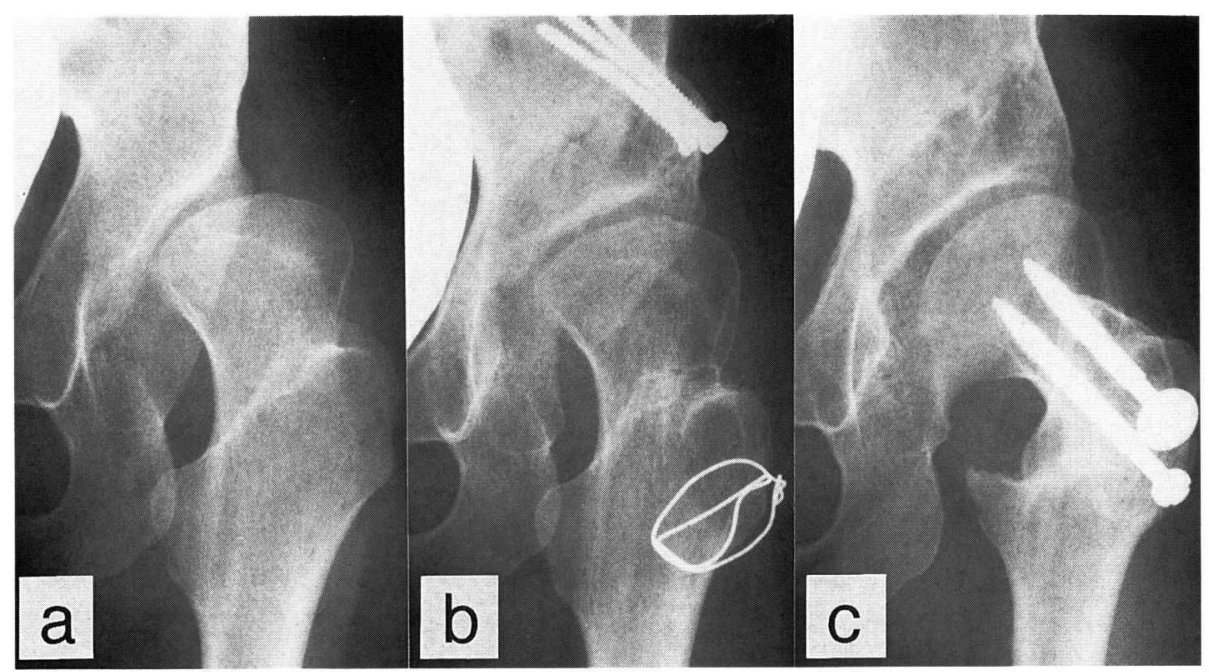

図 416 歳女性, 前関節症. 術前（a ），極めて高度な臼蓋形成不全と強い前捻，外反股を呈し，手術によ る被覆は不十分で（b)，疼痛の改善も不十分であったため，西尾式弯曲内骨切り術を追加した（c）. 


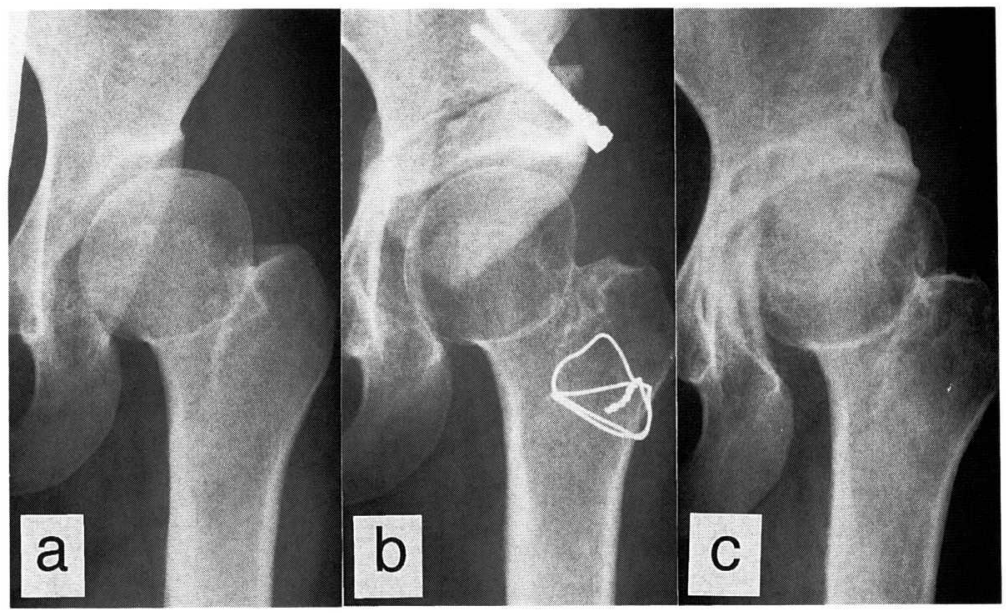

図 $5 \quad 17$ 歳女性, 前関節症. 術前 (a) 骨頭および頸部の軽度の変形と強い前捻を認める. 手術による外側 の被覆は良好であるが䨘骨田は後方へ移動し前方の被覆が不良となり（b)，術後 1 年頃から関節裂隙 の狭小化と亜脱且が進行し, 術後 2 年 (c) では関節裂隙は消失し, 骨頭に著名な骨轓形成をみる.

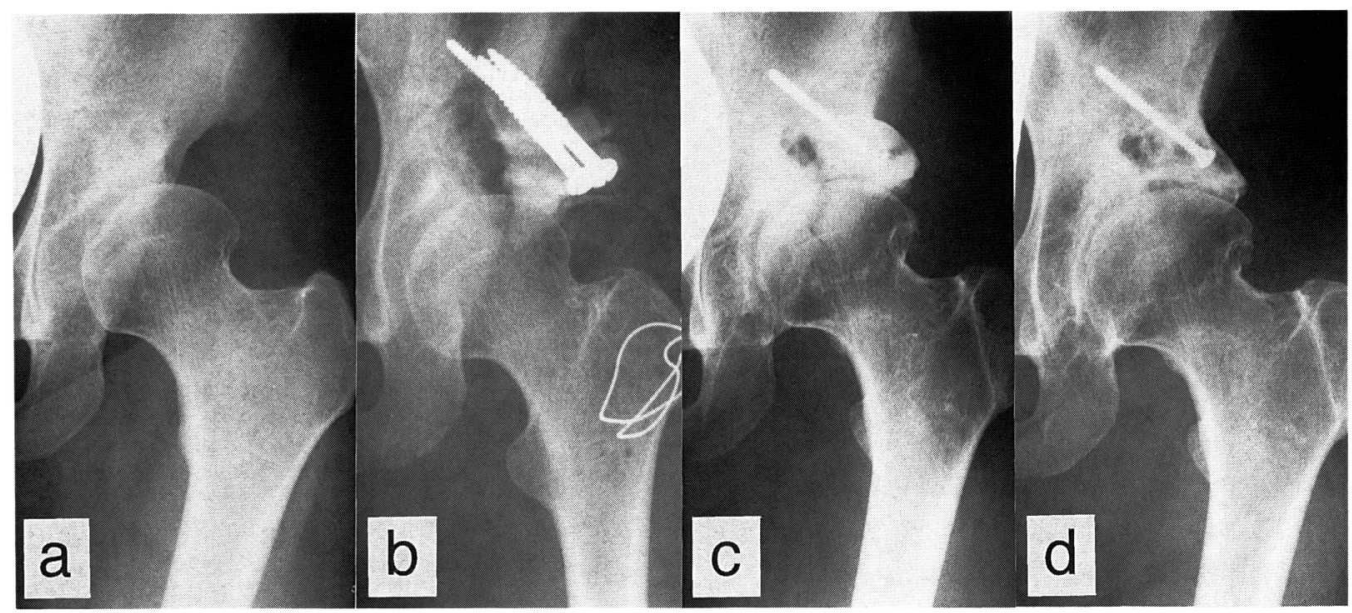

図 620 歳女性, 初期関節症. 術前 ( a ), 臼蓋の骨硬化と囊胞を認めるが裂隙の狭小化はない, 術中, 荷重部の関節軟 骨へ切り込み（b）が生じた. 2 年後 (c), 関節裂隙は狭小化し骨硬化も強く骨頭は外方化し関節症は進行してい るものの臨床症状は改善し, 術後 10 年 (d) では関節裂隙はやや拡大し, リモデリングにより適合性も改善しては いるが現在 30 歳と若く, 今後の経過が危惧される. JOA スコアは術前 80 点, 術後 2 年 90 点, 術後 10 年で 90 点 と現在のところ良好である.

節症の 1 関節に見られ，可動域のスコアを悪化させた が, 疼通は軽快し歩行能力も保たれ, 成績は良い. 坐 骨神経麻痺が 1 関節で生じ, これに対しては神経剥離 術を行ったが, 軽い腓骨神経領域の麻痺を残存してい る. 移動骨片と骨盤との間に間隙が生じた 3 関節で骨 癒合の遷延が見られた. 深部感染はなかったが, 皮下 血腫を生じた例で表層の感染を疑わせる症状が数例見
られたため, 持続吸引のチューブを骨切り部だけでな く皮下にも留置するようにして以降は, 皮下血腫はみ られていない.

$$
\text { 考察 }
$$

寛骨臼移動術は寛骨臼形成不全に対して寛骨臼を掘 り出して移動し骨頭を被覆する手術で, 関節軟骨によ 
り被覆するという点で Chiari 骨盤骨切り術 (1955) とは明かに異なる画期的な手術である，その後, 飯野 （1968），田川（1978）らによって追試され，また外国 においてあ Wagner (1965), Tonnis (1979) らによ り同様の手術が報告されてきている. 現在我が国で最 あ普及している田川法（寛骨臼回転骨切り術）と寛骨 臼移動術との大きな違いは, 田川法が大転子を切骨し ないのに対して寛骨臼移動術は大転子を切骨すること と, 田川法では移動骨片との間に骨移植を行うのに対 して寛骨臼移動術では骨移植を行わないことの 2 点で ある. しかし，その後田川法を大転子を切骨して行う という変法も現れ，さらには寛骨臼移動術そのあのを 寛骨臼回転骨切り術の変法と誤って報告されるといっ た混乱も生じている.

今回の調查で第一に明かになった点は, 術後成績は 術前のX線病期分類に大きく依存し，前関節症や初期 関節症では成績が良好であるが進行期では成績はやや 劣り, 末期関節症では一部の症例を除けば症状の改善 が不十分であることである。しかしながら，末期例を 含めた全症例の中で, 現在までの時点で内反骨切り術 の追加例が 1 関節あるものの, 人工関節置換術を行っ た例はなく，この事実は本手術の優秀性を示唆するも のである. 比較的成績が劣っている末期例等では可動 域制限はかなり高度となることが多いが, 疼痛の程度 は中程度であることが多く，寛骨臼の移動による関節 の安定性の獲得が本法の優れた点であり, 人工関節置 換術が少ない原因でもあると考える.

寛骨臼移動術は骨性の田底肥厚部の切除が容易で内 方化が得られ易いが，骨移植は原則として行わないの で, 骨頭は平均的にはやや上方へ移動する. JOA ス コアと骨頭の移動方向の関連の検討からは, 上方への 移動の有無は成績とは相関は見られないが，内方への 移動の有無は統計学的に有意に成績と相関し, 骨頭の 内方化を得た関節で成績がよい結果であった，骨頭の 内方化は股関節にかかる合力を減少させることが生体 力学的解析により示されているが, 今回の検討により 臨床例からもこのことが証明された。

成績不良例の検討からは，前および初期関節症では 被覆不十分（前方および側方）や外方化などが成績を 不良としており，適切な手術手技で行えば，安定した 成績が期待できると考えている．しかしながら臼蓋形 成不全が著しく高度な例や，外反股変形がある例では 寛骨臼移動術単独では対処が困難な場合もあり，内反
骨切り術の併用屯考慮すべきである，一方，進行期お よび末期では被覆が十分に出来なかったり, 骨頭変形 などによる関節適合性の不良などが成績不良の原因と なっているが，進行期や末期例では手技上，良好な被 覆を得るのが困難なことも多く，また関節適合性を改 善することあ難しいことが多いため，進行期および末 期の本法の適応にはおのずと限界があることを理解し， その決定には慎重でなくてはならない.

重篤な合併症としては坐骨神経麻盘や高度の異所性 骨化が各 1 例にみられ, 術中操作は愛護的に行うこと が重要である，骨盤は良好な血行を有しており，一般 に骨癋合は良好であるが，初期の手術例で骨片間に大 きな間隙を残し遷延瘉合が認められた。このような骨 癒合の遷延は，間隙に骨移植することでその後は発生 していない，骨壊死か疑われた症例が 1 関節見られた が，関節包以外の連続が断たれ血行は $1 / 3$ 程度まで減 少するとの報告むみられるが，移動骨片の壊死の発生 は稀である. 荷重部関節面への切り込みは 2 関節にみ られ，初期関節症の 1 関節はリモデリングにより幸い 臨床成績は現在のところ良好であるが，X線上関節症 変化は進行している。 あう 1 例は末期関節症で臨床成 績は不良であった．関節面への切り込みは関節症を進 行させる原因となるので，厳に慎まなければならない，

今回の調查結果から寛骨臼移動術の手術適応を考え てみると，亜脱臼性股関節症のうち前，および初期関 節症は極めて良い適応である．臼蓋形成不全が比較的 軽い症例では侵襲が小さい内反骨切り術で対処できる ので, 適応は中等度から高度の毛蓋形成不全を有する 症例となる．寛骨臼移動術之内反骨切り術の適応の境 界は, 内反骨切りの成績を考虑して, $\mathrm{CE}$ 角 0 度, 白 蓋荷重部傾斜角 30 度程度を一応の目安と考えている. 年齢的にはY 軟骨が閉鎖する 12 13 歳から 50 歳台ま でが良い適応である，進行期関節症では関節適合性が 術後成績に大きく関係してくるので，骨頭が円形や卵 形を呈し外転位で関節裂䏚の拡大と適合性の改善がみ られる症例が良い適応となる。骨頭变形が強く，外転 位での適合性の不良なすのは成績が安定せず，適応は 慎重に考慮すべきであるが，比較的若年層では考慮す べき手術である，適合性を改善するために外反骨切り 術を併用することも一つの方法である．末期関節症で は成績は一層不安定であるが，20３0 歳台といった 若い症例に対しては骨頭温存する意味であ骨切り術の 持つ意味は大きく, 比較的外転が可能な症例では適応 
となることあある. しかしながら, 50 歳以後の症例 には通常適応とならない，また内転拘縮が強い症例で はむしろ外反骨切り術が考慮されるべきで, 片側例で は関節固定術も考慮されてよい。

\section{ま と め}

1) 寛骨臼移動術後 2 年以上の経過を観察しえた 102 関節の成績を検討した.

2）最終時の成績は優 $42 \%$, 良 $26 \%$, 可 $23 \%$, 不 可 $9 \%$ で, X線病期が進むにつれ術後成績は劣ってお り, 本手術の良い適応は前関節症や初期関節症, おょ び骨頭変形の軽い進行期関節症である.

3）十分な被覆や内方化が得られないなど不適切な
手技により成績が不良な例がみられ，適切な手技が重 要である.

4) 進行期および末期例に対しても24関節で本手 術が施行されているが術後に人工関節置換術に至った 例はなく，本手術の優秀性を示している.

\section{参 考 文 献}

1）江口正雄ほか：変形性股関節症に対する寛骨且移動術. 日整会誌, $65 ：$ S 247, 1991.

2）香月一朗ほか：当科における寛骨臼移動術の成績. Hip Joint, $11: 262-266,1985$.

3）西尾篤人：先天性股関節脱臼に対する䯣臼移動による 観血的整復術. 日整会誌, $30: 483,1956$. 